\title{
On the relationship between the Apollo 16 ancient regolith breccias and feldspathic fragmental breccias, and the composition of the prebasin crust in the Central Highlands of the Moon
}

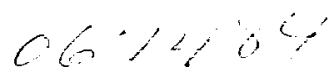

\author{
Department of Earth and Planetary Sciences and McDonnell Center for the Space Sciences, \\ Washington University, St. Louis, Missouri 63130, USA \\ Author's e-mail address: rlk@levee.wustl.edu
}

(Received 1995 June 19; accepted in revised form 1996 January 31)

\begin{abstract}
Two types of texturally and compositionally similar breccias that consist largely of fragmental debris from meteorite impacts occur at the Apollo 16 lunar site: Feldspathic fragmental breccias (FFBs) and ancient regolith breccias (ARBs). Both types of breccia are composed of a suite of mostly feldspathic components derived from the early crust of the Moon and mafic impact-melt breccias produced during the time of basin formation. The ARBs also contain components, such as agglutinates and glass spherules, indicating that the material of which they are composed occurred at the surface of the Moon as fine-grained regolith prior to lithification of the breccias. These components are absent from the FFBs, suggesting that the FFBs might be the protolith of the ARBs. However, several compositional differences exist between the two types of breccia, making any simple genetic relationship implausible. First, clasts of mafic impact-melt breccia occurring in the FFBs are of a different composition than those in the ARBs. Also the feldspathic "prebasin" components of the FFBs have a lower average $\mathrm{Mg} / \mathrm{Fe}$ ratio than the corresponding components of the ARBs; the average composition of the plagioclase in the FFBs is more sodic than that of the ARBs; and there are differences in relative abundances of rare earth elements. The two breccia types also have different provenances: the FFBs occur primarily in ejecta from North Ray crater and presumably derive from the Descartes Formation, while the ARBs are restricted to the Cayley plains. Together these observations suggest that although some type of fragmental breccia may have been a precursor to the ARBs, the FFBs of North Ray crater are not a significant component of the ARBs and, by inference, the Cayley plains. The average compositions of the prebasin components of the two types of fragmental breccia are generally similar to the composition of the feldspathic lunar meteorites. With $30-31 \% \mathrm{Al}_{2} \mathrm{O}_{3}$, however, they are slightly richer in plagioclase than the most feldspathic lunar meteorites $\left(-29 \% \mathrm{Al}_{2} \mathrm{O}_{3}\right)$, implying that the crust of the early central nearside of the Moon contained a higher abundance of highly feldspathic anorthosite than typical lunar highlands, as inferred from the lunar meteorites. The ancient regolith breccias, as well as the current surface regolith of the Cayley plains, are more mafic than (1) prebasin regoliths in the Central Highlands and (2) regions of highlands presently distant from nearside basins because they contain a high abundance $(-30 \%)$ of mafic impact-melt breccias produced during the time of basin formation that is absent from other regoliths.
\end{abstract}

\section{INTRODUCTION}

Fragmental breccias are common products of large meteorite impacts on the Earth and Moon. They consist of clastic fragments of various target lithologies that were lithified by the heat and shock of impact. Also known as clastic matrix breccias, fragmental breccias occur in continuous ejecta deposits outside craters and as layers inside craters (Stöffler et al., 1979). At the Apollo 16 landing site in the lunar Central Highlands, the most common rock type recovered from the rim of North Ray crater $(-1 \mathrm{~km}$ diameter) is "feldspathic fragmental breccia," i.e., fragmental breccia that consists largely of plagioclase-rich fragments (Stöffler et al., 1980; James, 1981).

Regolith breccias are known from airless bodies, i.e., the Moon and meteorite parent bodies. Although also dominated by rock and mineral fragments, regolith breccias contain components unique to surface regolith, namely, glass spherules, agglutinates, and gases derived from solar and galactic irradiation. Many regolith breccias have a glassy matrix, but those that do not can be difficult to distinguish from fragmental breccias. For example, Apollo 16 samples 63588 and 63595 have been classified as feldspathic fragmental breccias by Stöffler et al. (1985) and as regolith breccias by McKay et al. (1986).
A subset of regolith breccias from Apollo 16 is designated "ancient" because the breccias are composed of regolith that existed during the time of basin formation $\sim 3.9 \mathrm{Ga}$ ago (McKay et al., 1986; Wentworth and McKay, 1988b). The ancient regolith breccias (ARBs) and feldspathic fragmental breccias (FFBs) of Apollo 16 are similar to each other texturally (Wentworth and McKay, 1988a) and contain many of the same nominal clastic components, e.g., anorthosites, granulitic breccias, and impact-melt breccias. In particular, both FFBs and $A R B s$ contain clasts of mafic (17-22\% $\left.\mathrm{Al}_{2} \mathrm{O}_{3}\right)$, KREEPbearing impact-melt breccias that were produced during the time of basin formation. Because they are more mafic than the present highlands surface, these melt breccias are believed to be dominated largely by material from the lower crust or upper mantle of the Moon that was excavated and mixed by large impacts (e.g., Ryder and Wood, 1977). However, a significant difference between the FFBs and ARBs is that the ARBs contain glasses with a wide range of compositions, including KREEP-rich and ultrahigh- $M g^{\prime}$ varieties (Wentworth and McKay, $1988 \mathrm{~b} ; \mathrm{Mg}^{\prime}=\mathrm{mol} \% \mathrm{Mg} /[\mathrm{Mg}+\mathrm{Fe}]$ ). Such glasses, which presumably are derived by impact mixing at the surface, are absent from the FFBs. This observation led Takeda et al. (1990) to suggest that the FFBs might be precursors to the ARBs. 
The Apollo 16 FFBs and ARBs, as well as any relationship they may have to each other, are important for understanding the geologic history of the Central Highlands because they each represent a different stage, process, or provenance in that history. They are also important for the purpose of interpreting the lunar meteorites because all of the known feldspathic lunar meteorites are fragmental breccias or regolith breccias. In this paper, I argue that it is unlikely that the Apollo 16 ARBs derive from the FFBs of North Ray crater in any simple cvolutionary sense because both the basinera components (the mafic impact-melt breccias) and the "prebasin" (KREEP-poor, feldspathic) components differ in the two types of breccia. I also show that the prebasin portions of the Apollo 16 ARBs and FFBs bear a compositional similarity to the feldspathic lunar meteorites and that differences in $\mathrm{Mg}^{\prime}$ between the prebasin components of the ARBs and FFBs are similar in magnitude to those observed among feldspathic lunar meteorites.

\section{EXPERIMENTAL}

Samples of ARB were coarsely crushed with an agate mortar and pestle and fragments dominated by single clasts were extracted. Matrix from the clast samples were trimmed using a stainless steel chisel. A total of 71 subsamples, each consisting of portions of single clasts (possibly with minor adhering matrix), was obtained from six breccias (samples 60016, $60019,61135,65095,66035$, and 66075) and analyzed by instrumental neutron activation analysis (INAA; Korotev, 1991). The average mass of the clast subsamples was $15 \mathrm{mg}$. Subsequent to INAA, thin sections were prepared of some of the clasts. In addition to clasts, 15 subsamples dominated by fine-grained matrix from these same six ARBs were analyzed; 4 subsamples of FFB sample 63578 (20-50 mg each); and 12 samples of fine fines (unsieved or $<1 \mathrm{~mm}$ ) from station 11 at North Ray crater, including some previously unstudied residual fines from collection bags accompanying rocks (see Table 6 of Ulrich, 1981).

\section{RESULTS}

Compositional comparisons and mixing relationships discussed in this section are supported by mass-balance calculations that include all major elements and all analyzed minor and trace lithophile elements. For purpose of illustration, however, only plots of $\mathrm{Sm}$ vs. Sc are presented because these two elements are particularly effective for showing such relationships in Apollo 16 polymict materials (e.g., McKay et al., 1986; Korotev, 1991, 1994). Scandium, which is carried primarily in pyroxenes, is a measure of "maficness" and, consequently, Sc concentrations generally correlate inversely with those of $\mathrm{Al}_{2} \mathrm{O}_{3}$ in polymict materials from Apollo 16 (e.g., Korotev, 1994). Samarium is a representative incompatible trace element (ITE) and, for convenience, I use "Smrich" and "Sm-poor" as modifiers to indicate that a lithology or component is rich or poor in all ITEs.

\section{Ancient Regolith Breccias}

Ancient regolith breccias are not as compositionally uniform as are mature soils $(<1 \mathrm{~mm}$ fines) from Apollo 16. Small subsamples of any given ARB, even "matrix" subsamples selected to be free of large clasts, are variable in composition (Fig. la) because of variability in clast abundance and composition (averages for each sample are presented in Table 1). As noted by McKay et al. (1986), there is a trend among matrix subsamples of increasing concentration of ITEs, such as Sm, with increasing concentrations of Sc and other elements carried by mafic phases (Fig. 1a). Subsamples of some breccias (e.g., 66035 and 66075) span nearly the entire range of compositions that are seen among all ARBs. Although the different breccias are petrographically diverse (McKay et al., 1986; Simon et al., 1988), their matrix-rich subsamples all plot along the same $\mathrm{Sc}-\mathrm{Sm}$ trend. This suggests that all ARBs are composed of the same kinds of components and that the trend represents two-component mixing. But what are those components?

Clasts from ARBs are even more variable in composition but most fall into one of two compositional suites, each of which defines a compositional trend on the Sc-Sm plot (Fig. Ib). The Smrich suite is defined mainly by clasts with $>8 \mu \mathrm{g} / \mathrm{g} \mathrm{Sm}$. All clasts of this type are Sm-rich mafic impact-melt breccias of compositional groups 1 and 2 (Korotev, 1994). They correspond to "crystalline/ melt matrix" breccias (McKay et al., 1986) and "poikilitic rocks" and "impact melts" (Simon et al., 1988), which dominate lithic clasts observed petrographically in ARBs. The mafic impact-melt breccias are the principal carriers of incompatible elements, like Sm, in the ARBs because no igneous-textured lithic clasts that are rich in incompatible elements occur in the breccias. I refer to the mafic impact-melt breccias as the "basin" component because they are generally believed to be direct products of impact melting and assimilation of KREEP that occurred during formation of basins or large craters that formed contemporaneously (e.g., James et al., 1984; Spudis, 1984; Taylor et al., 1991). Indeed, the time of basin formation, $\sim 3.9 \mathrm{Ga}$ ago, has been established mainly by the crystallization age of mafic impact-melt breccias. On the Sc-Sm plot, the extrapolation in the low-Sm direction of the trend of the mafic melt-breccia clasts is nearly colinear with the mixing trend defined by the matrix subsamples (Fig. 1b).

Of the 52 clasts of mafic impact-melt breccia, $66 \%$ are of group2 composition (nominally, $8-16 \mu \mathrm{g} / \mathrm{g} \mathrm{Sm}$ ) and the remaining $34 \%$

TABLE 1. Mass-weighted mean INAA results for "matrix" subsamples of ancient regolith breccias (ARBs) and feldspathic fragmental breccia (FFB) 63578 .

\begin{tabular}{|c|c|c|c|c|c|c|c|c|}
\hline & & & $\mathrm{AR}$ & Bs & & & & \\
\hline & 60016 & 60019 & 61135 & 65095 & 66035 & 66075 & 63578 & $(\%)$ \\
\hline$N$ & 2 & 6 & 1 & 1 & 3 & 2 & 4 & 1 \\
\hline $\mathrm{Na}_{2} \mathrm{O}$ & 0.504 & 0.475 & 0.510 & 0.402 & 0.474 & 0.505 & 0.460 & 2 \\
\hline $\mathrm{CaO}$ & 16.0 & 15.0 & 16.4 & 17.7 & 15.6 & 15.7 & 14.6 & 3 \\
\hline $\mathrm{FeO}_{\mathrm{t}}$ & 4.13 & 5.33 & 4.10 & 1.92 & 4.69 & 4.17 & 4.65 & 2 \\
\hline $\mathrm{Sc}$ & 6.59 & 8.70 & 5.96 & 3.16 & 7.25 & 6.14 & 6.40 & 2 \\
\hline $\mathrm{Cr}$ & 542 & 771 & 468 & 260 & 673 & 498 & 780 & 2 \\
\hline $\mathrm{Co}$ & 17.7 & 30.3 & 17.1 & 8.1 & 25.3 & 18.4 & 23.5 & 2 \\
\hline $\mathrm{Ni}$ & 207 & 439 & 195 & 120 & 354 & 225 & 258 & 5 \\
\hline $\mathrm{Sr}$ & 202 & 174 & 182 & 176 & 183 & 185 & 167 & 7 \\
\hline $\mathrm{Zr}$ & 147 & 268 & 117 & 70 & 214 & 127 & 63 & 8 \\
\hline $\mathrm{Ba}$ & 112 & 187 & 101 & 57 & 150 & 101 & 72 & 4 \\
\hline $\mathrm{La}$ & 10.19 & 18.83 & 9.19 & 4.01 & 15.6 & 8.84 & 4.36 & 2 \\
\hline $\mathrm{Ce}$ & 26.2 & 48.5 & 23.9 & 10.3 & 40.1 & 22.4 & 11.0 & 3 \\
\hline $\mathrm{Sm}$ & 4.69 & 8.49 & 4.22 & 1.86 & 6.93 & 4.04 & 1.86 & 2 \\
\hline $\mathrm{Eu}$ & 1.22 & 1.27 & 1.24 & 0.96 & 1.23 & 1.19 & 0.95 & 2 \\
\hline $\mathrm{Tb}$ & 0.95 & 1.71 & 0.87 & 0.38 & 1.41 & 0.81 & 0.41 & 4 \\
\hline $\mathrm{Yb}$ & 3.36 & 5.98 & 2.97 & 1.29 & 4.92 & 2.89 & 1.90 & 3 \\
\hline Lu & 0.448 & 0.810 & 0.401 & 0.179 & 0.669 & 0.396 & 0.264 & 3 \\
\hline $\mathrm{Hf}$ & 3.56 & 6.44 & 3.18 & 1.36 & 5.27 & 3.01 & 1.58 & 3 \\
\hline $\mathrm{Ta}$ & 0.39 & 0.72 & 0.33 & 0.15 & 0.57 & 0.34 & 0.26 & 4 \\
\hline Ir & 5.1 & 11.2 & 6.0 & 1.7 & 8.3 & 5.5 & 12.6 & -20 \\
\hline $\mathrm{Au}$ & 4.4 & 9.0 & 3.2 & 2.8 & 7.8 & 4.1 & 2.7 & -20 \\
\hline $\mathrm{Th}$ & 1.73 & 3.12 & 1.45 & 0.64 & 2.50 & 1.37 & 1.28 & 3 \\
\hline U & 0.42 & 0.86 & 0.38 & 0.18 & 0.67 & 0.36 & 0.34 & 7 \\
\hline mass & 94 & 181 & 64 & 45 & 101 & 56 & 228 & - \\
\hline
\end{tabular}

Values in $\mu \mathrm{g} / \mathrm{g}$, except oxides in mass percent, Ir and $\mathrm{Au}$ in $\mathrm{ng} / \mathrm{g}$, and total mass of analyzed subsamples in $\mathrm{mg}$. $N=$ number of subsample analyses averaged. $\mathrm{FeO}_{\mathrm{t}}=$ total $\mathrm{Fe}$ as $\mathrm{FeO}$. Unc. $=$ one standard deviation estimate of analytical uncertainty for a single analysis (percent of concentration value). 

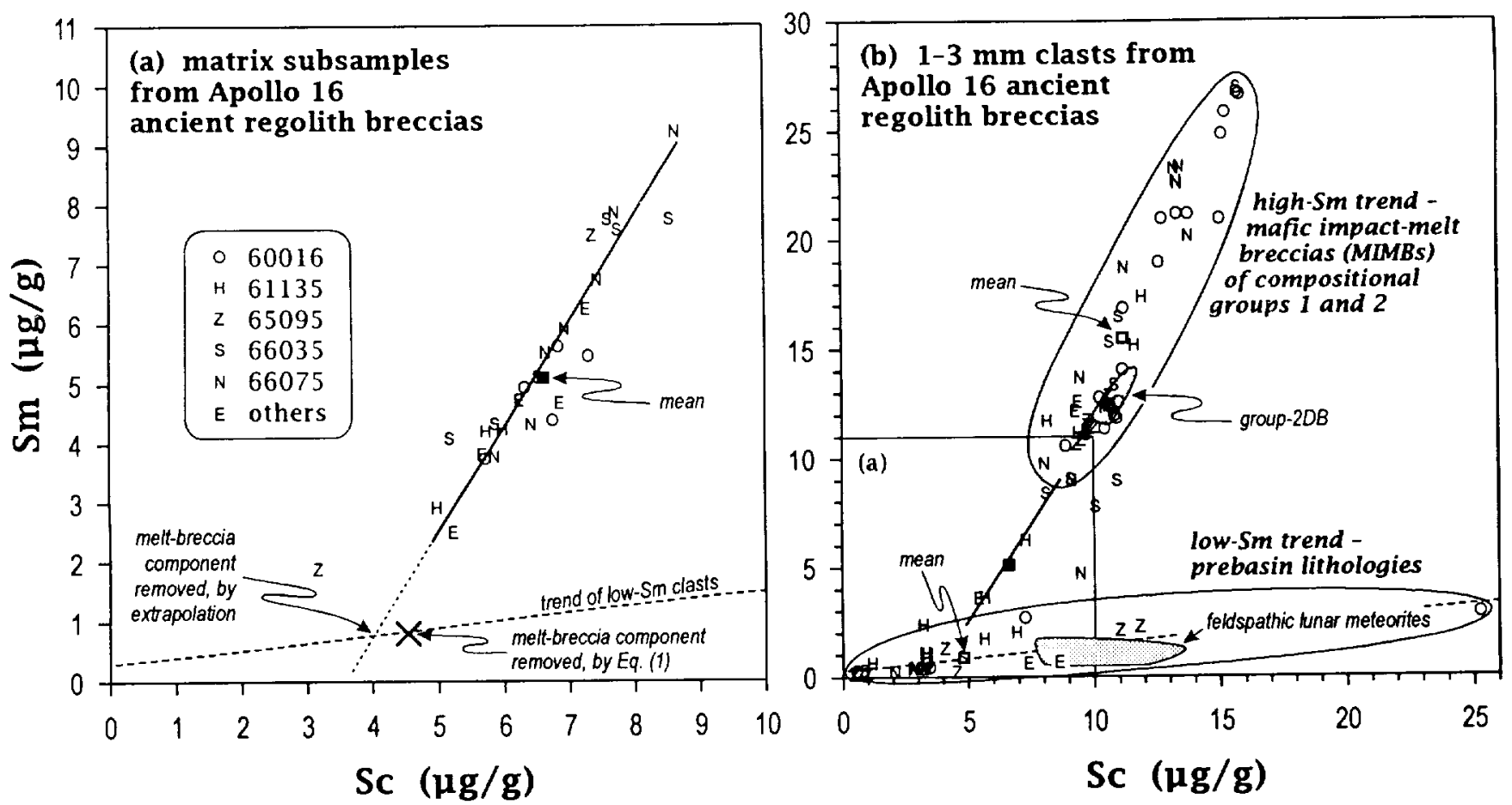

FIG. 1. Variation of $\mathrm{Sm}$ and Sc concentrations in matrix subsamples (a) and clasts (b) from ancient regolith breccias. (a) The "matrix" subsamples are FIG. 1. Variation of $\mathrm{Sm}$ and $\mathrm{Sc}$ concentrations in matrix subsamples (a) and clasts (b) from ancient regolith breccias. (a) The among subsamples of a single rock $(e . g, 66035)$. The solid line indicates the trend of the data and is defined by points $(4.9,2.34)$ and $(8.7,9.05)$. The solid square represents the mean composition of the matrix subsamples (Table 3 , column 1). The dashed line (in a and b) is a least-squares fit to the Smsolid square represents the mean composition of the matrix subsamples (Table 3 , column 1 ). The dapolation of the solid line (dotted) and the dashed line (at $4.0 \mu \mathrm{g} / \mathrm{g} \mathrm{Sc}$ and $0.80 \mu \mathrm{g} / \mathrm{g} \mathrm{Sm}$ ) provides one estimate of Sc and Sm concentrations of the prebasin regolith (i.e., the composition of ancient regolith after

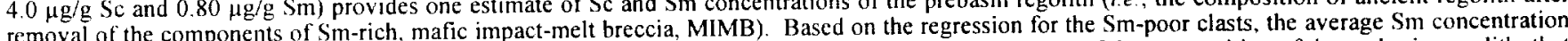
removal of the components of Sm-rich, mafic impact-melt breccia, MIMB). Based on the regression for the of clasts with $4 \mu \mathrm{g} / \mathrm{g} \mathrm{Sc}$ is $0.80 \pm 0.24 \mu \mathrm{g} / \mathrm{g}(95 \%$ confidence limit). The X represents a different estimate of the composition of the prebasin regolith, that from Table 3 (column 5), which is based on averages (Eq. 1), not trends. The slight offset in the two estimates occurs because the extrapolation of the trend of the matrix samples into the field of the MIMBs (b) does not exactly intersect the average composition of the MIMB clasts, which was used to trend of the matrix samples into the fleld of the Mi MBs ol) does no "E" are 61516, 63588, 63595, 65715, and 66036 (one subsample each). Plot (a) is restricted to "ancient" samples for which ${ }^{40} \mathrm{Ar} /{ }^{36} \mathrm{Ar}>12$ (McKay et al, 1986$)$, thus sample $60019\left({ }^{40} \mathrm{Ar} /{ }^{36} \mathrm{Ar}=9.7\right)$ is not included $(60019$ subsamples

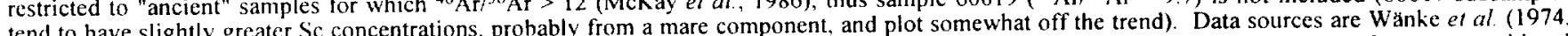
tend to have slightly greater $S$ c concentrations, probably from a mare component, and plot somewhat off the trend (198), and this work. In plot (b), most clasts from ARs lie on one of two compositional trends. The Sm-rich trend is defined by MIMBs similar to those found as large rocks about the site. Most of the clasts correspond to compositional group trends. The Sm-rich trend $16 \mu \mathrm{g} / \mathrm{g} \mathrm{Sm}$ correspond to groups IM and IF ("IKFM;" Korotev, 1994). The Sm-poor trend is defined by Sm-poor 2DB ("VHA"); those with $>16 \mu \mathrm{g} / \mathrm{g} \mathrm{Sm}$ correspond to groups $\mathrm{M}$ and $\mathrm{F}$ ("LKF;" Korotev, lithologies, such as anorat meteorites is shown (Koeberl et al, 1989 ; characteristic of the feldspathic lunar meteorites, symbolized with an "E" are all from 60019. The mean composition of the MIMB clasts and the Sm-poor

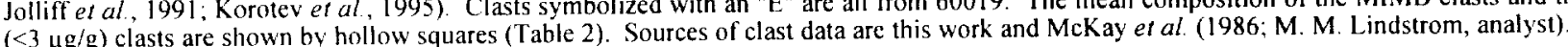

of group 1 composition $(>16 \mu \mathrm{g} / \mathrm{g} \mathrm{Sm})$. Of the group-2 clasts, $\sim 10$ are indistinguishable from the melt phase associated with the Apollo 16 dimict breccias (group 2DB) and the others are similar. Significantly, none are unambiguously like the group -2 melt found in FFBs (group 2NR, helow). Although the small clast sizes and coarse-grained texture make such assignments tentative, the 18 melt-breccia clasts of group- 1 composition are evenly split between groups $1 \mathrm{M}(\mathrm{Cr} / \mathrm{Sc}>92)$ and $1 \mathrm{~F}(\mathrm{Cr} / \mathrm{Sc}<92)$, based on $\mathrm{Cr} / \mathrm{Sc}$ ratios (and, by inference, $M g^{\prime} ;$ see Figs. $7 \mathrm{a}$ and 11 of Korotev, 1994).

The Sm-poor suite of clasts consists of plutonic rocks (anorthosite. norite, troctolite, i.e., the "ANT suite" clasts of McKay et al. 1986) and granulitic breccias, impact-melt breccias, and glasses, which are derived ultimately from plutonic rocks. I refer to the Sm-poor components as the "prebasin" components because most represent (e.g., anorthosites) or derive by impact metamorphism from (e.g., granulitic breccias) lithologies that occurred in the upper crust prior to basin formation. It is likely that some or all of the "prebasin" clasts were modified during the basin-forming era.
However, the treatment presented here assumes that, except for melting and physical mixing, any such metamorphism had little effect on composition (i.e., no gross chemical fractionations occurred).

The prebasin clasts are lithologically and compositionally diverse. Six of the analyzed clasts are anorthosites, consisting of nearly pure plagioclase $(<2 \mu \mathrm{g} / \mathrm{g} \mathrm{Sc}$; Fig. $1 \mathrm{~b})$. Twelve clasts ("noritic anorthosites" of Table 2$)$ are more mafic $(2-5 \mu \mathrm{g} / \mathrm{g} \mathrm{Sc})$ and generally similar to each other in composition. They are characterized by low concentrations of $\mathrm{Ni}(<100 \mu \mathrm{g} / \mathrm{g})$ and ITEs $(<2 \mu \mathrm{g} / \mathrm{g}$ $\mathrm{Sm}$ ). From their composition, appearance, and a cursory petrographic examination of some of them, most of the clasts of noriticanorthosite composition are granulitic breccias or feldspathic impact-melt breccias. Two clasts from 61135 are melt breccias of troctolitic-anorthosite composition (low $\mathrm{Ca}$ and $\mathrm{Na}$, high $\mathrm{Cr}$; Table 2, column 3). Samarium-poor clasts more mafic than the noritic anorthosites ( $>5 \mu \mathrm{g} / \mathrm{g} \mathrm{Sc}$ ) are dissimilar to each other, so no average is presented in Table 2; this group includes granulitic breccias, impact-melt breccias, and an unusually mafic glassy breccia (Table 
2. column 6). Clasts that plot between the fields of the Sm-rich, mafic impact-melt breccias and the Sm-poor clasts of Fig. Ib are either impact-melt breccias of intermediate composition (groups $2 \mathrm{M}$ and $2 \mathrm{~F}$ of Korotev, 1994) or melt-breccia clasts with adhering feldspathic matrix (Table 3, footnote). All such clasts are rich in siderophile elements ( $\mathrm{Ni}: 220-1200 \mu \mathrm{g} / \mathrm{g}$ ).

The fine-grained matrix of the $A R B$ s is presumably composed of the same types of lithologies as the clasts, although not necessarily in the same relative proportions. Because average concentrations of ITEs in the clasts (Table 2, column 7) are greater than those of the matrix samples (Table 1), it is likely that the suite of clasts analyzed here overrepresents the ITE-rich. mafic impact-melt breccias. This sampling bias results in large part from the greater coherency of the melt-breccia clasts. Although the field of all clasts outlines a distribution of points that is roughly triangular on plots such as Fig. Ib, matrix subsamples define a linear trend (Fig. la). Regolith breccias that consist, for example, of mixtures of mafic melt breccia and highly feldspathic anorthosite (clasts with $<2 \mu \mathrm{g} / \mathrm{g}$ $\mathrm{Sc})$ or mafic melt breccia and norite $(>15 \mu \mathrm{g} / \mathrm{g} \mathrm{Sc})$ do not occur. Together, these observations indicate that the relative abundances of the various lithologies of the low-Sm trend are similar in all $A R B S$

TABLE 2. Mean INAA-resulfs for clasts from ancient regolith breccias

\begin{tabular}{|c|c|c|c|c|c|c|c|}
\hline & $\underset{1}{\text { Anorth. }}$ & $\begin{array}{c}\text { Noritic } \\
\text { Anorth. } \\
\quad 2\end{array}$ & $\begin{array}{l}\text { Trocto- } \\
\text { litic } \\
\text { anorth. } \\
\text { melt } \\
3\end{array}$ & $\begin{array}{c}\mathrm{All}<3 \\
\mathrm{Hg} / \mathrm{g} \\
\mathrm{Sm} \\
4\end{array}$ & $\begin{array}{c}\text { Mafic } \\
\text { impact- } \\
\text { melt } \\
\text { breccias } \\
5\end{array}$ & $\begin{array}{c}60016 \\
\mathrm{c} 06 \\
6\end{array}$ & $\begin{array}{l}W t^{\prime} d \\
\text { mean } \\
7\end{array}$ \\
\hline$N$ & 6 & 12 & 2 & 28 & 52 & 1 & 85 \\
\hline $\mathrm{Na}_{2} \mathrm{O}$ & 0.422 & 0.51 & 0.205 & 0.447 & 0.523 & 0.397 & 0.481 \\
\hline $\mathrm{CaO}$ & 18. & & 8.5 & & 12.4 & 11.1 & 14,1 \\
\hline $\mathrm{Sc}$ & 0.70 & 3.36 & 3.29 & 4.81 & 11.24 & 25.2 & 8.66 \\
\hline $\mathrm{Cr}$ & 37 & 220 & 1200 & 394 & 1080 & 213 & 802 \\
\hline $\mathrm{FeO}_{\mathrm{t}}$ & 0.40 & 2.16 & 4.84 & 3.04 & 7.49 & 10.80 & 5.80 \\
\hline $\mathrm{Co}$ & 0.92 & 5.37 & 23.6 & 13.8 & 48.0 & 20.3 & 35.6 \\
\hline $\mathrm{Ni}$ & 7 & 28 & 181 & 156 & 767 & 70 & 539 \\
\hline $\mathrm{SI}_{\mathrm{I}}$ & 187 & 216 & 83 & 186 & 178 & 160 & 176 \\
\hline $\mathrm{Ba}$ & 14 & 28 & 23 & 31 & 333 & 84 & 214 \\
\hline La & 0.52 & 1.38 & 2.21 & 1.85 & 34.1 & 4.52 & 21.6 \\
\hline $\mathrm{Sm}$ & 0.22 & 0.61 & 1.02 & 0.90 & 15.4 & 2.81 & 9.73 \\
\hline Eu & 0.91 & 1.18 & 0.44 & 1.01 & 1.58 & 1.19 & 1.34 \\
\hline $\mathrm{Tb}$ & 0.039 & 0.120 & 0.195 & 0.187 & 3.04 & 0.67 & 1.93 \\
\hline$Y b$ & 0.126 & 0.45 & 0.72 & 0.70 & 10.5 & 2.48 & 6.72 \\
\hline Lu & 0.016 & 0.064 & 0.100 & 0.098 & 1.45 & 0.36 & 0.92 \\
\hline $\mathrm{Ho}$ & 0.11 & 0.40 & 0.75 & 0.65 & 11.9 & 2.41 & 7.47 \\
\hline Ta & 0.009 & 0.050 & 0.080 & 0.083 & 1.29 & 0.26 & 0.83 \\
\hline Ir & $<2$ & 1.2 & 5.0 & 8.3 & 16.7 & 2.1 & 13.4 \\
\hline Au & $<2$ & $<2$ & 1.2 & 2.5 & 17.0 & 0.9 & 11.6 \\
\hline Th & 0.042 & 0.155 & 0.31 & 0.24 & 5.52 & 0.55 & 3.50 \\
\hline U & 0.014 & 0.043 & 0.090 & 0.066 & 1.48 & 0.16 & 0.94 \\
\hline & 81 & 164 & 42 & 426 & 803 & 7 & 1276 \\
\hline
\end{tabular}

Values in $\mu \mathrm{g} / \mathrm{g}$, except oxides in mass percent, Ir and $\mathrm{Au}$ in $\mathrm{ng} / \mathrm{g}$. and total analyzed sample (clast) mass in mg. $N$ - number of clasts analyzed and averaged $\mathrm{FeO} \mathrm{t}_{\mathrm{t}}=$ total $\mathrm{Fe}$ as $\mathrm{FeO}$. This table summarizes data for 71 clasts analyzed for this work plus 14 clasts for which data were presented previously in rigure 12 of Mckay et al (1986, this lab. M. M. Lindstrom, analyst) $1=$ simple mean of 6 anorthosite clasts $(i e$ all clasts with $\leq 1$ $\mu \mathrm{g} / \mathrm{g} \mathrm{Sc}$ ). $2=$ simple mean of 12 noritic anorthosite clasts (all clasts with $2-5 \mu \mathrm{g} / \mathrm{g}$ So). $3=$ simple mean of 2 troctoliticanorthositic melt breccias from $61135.4=$ simple mean of all clasts with $<3 \mu \mathrm{g} / \mathrm{g}$ Sm ("Sm-pour clasts"). 5 - simple mean of all clasts with $>8 \mu \mathrm{g} / \mathrm{g} \mathrm{sm} .6=$ unusually mafic, glassy breccia clast from 60016. 7 - mass-weighted mean of all analyzed clasts. and that these lithologies had a fine grain-size distribution and were mixed well prior to addition of the clasts of Sm-rich, matic melt breccias. In other words, the intersection of the two trends represents the composition of a prebasin regolith somewhere in the Apollo 16 region, and the trend of the matrix subsamples of Fig. la results from mixing of fragments of Sm-rich, mafic inclt breccia in varying proportions (10-50\%, below) with well-mixed old regolith. consisting of a mixture of Sm-poor lithologies. This same mixing effect was observed petrographically (liig. 2 of McKay et al. 1986) Thus, by extrapolation of the trend of the matrix subsamples in Fig. la to low Sm concentrations typical of the prebasin components $(<3$ $\mu \mathrm{g} / \mathrm{g} \mathrm{Sm})$, the component of mafic impact-melt breccia is effectively "removed." providing an estimate of the average Sc and Sm concentrations of the prebasin components (i.e., $4.0 \mu \mathrm{g} / \mathrm{g} \mathrm{Sc}$ and $0.80 \mu \mathrm{g} / \mathrm{g}$ Sm; Fig. 1).

TAB1.1: 3. Compositions of ancient regolith breccias from the ('ayley plains (ARB) and feldspathic fragmental breccias from the Descartes lormation at North Ray crater (F.B), with estimates of the composition of their matic impact-melt breccia and prebasin components and comparison to the two most feldspathic lunar metcorites.

\begin{tabular}{|c|c|c|c|c|c|c|c|c|}
\hline & \multirow{2}{*}{\multicolumn{2}{|c|}{ Means }} & \multirow{2}{*}{\multicolumn{2}{|c|}{$\begin{array}{l}\text { Mafic impact- } \\
\text { melt breccia }\end{array}$}} & \multirow{2}{*}{\multicolumn{2}{|c|}{$\begin{array}{l}\text { Estimated pre- } \\
\text { basin comp. }\end{array}$}} & \multicolumn{2}{|c|}{$\begin{array}{l}\text { l.unar } \\
\text { metcorites }\end{array}$} \\
\hline & & & & & & & & QUE: \\
\hline & ARB & FFB & ARB & FFB & ARBs & FFBs & 860132 & 93069 \\
\hline & 1 & 2 & 3 & 4 & 5 & 6 & & 8 \\
\hline $\mathrm{TiO}_{2}$ & 0.51 & 0.44 & 1.05 & 1.0 & 0.30 & 0.39 & 0.18 & 0.25 \\
\hline $\mathrm{Al}_{2} \mathrm{O}_{3}$ & 28.4 & 29.1 & 20.7 & 21.2 & 31.4 & 29.9 & 28.4 & 28.9 \\
\hline $\mathrm{FeO}_{1}$ & 4.21 & 3.78 & 8.35 & 7.69 & 2.64 & 3.39 & 4.28 & 4.44 \\
\hline $\mathrm{MgO}$ & 5.49 & 4.26 & 11.15 & 11.10 & 3.34 & 3.57 & 5.26 & 4.53 \\
\hline $\mathrm{CaO}$ & 16.1 & 16.4 & 12.29 & 12.65 & 17.6 & 16.8 & 16.4 & 16.5 \\
\hline $\mathrm{Na}_{2} \mathrm{O}$ & 0.49 & 0.54 & 0.523 & 0.486 & 0.48 & 0.54 & 0.44 & 0.35 \\
\hline Sc & 6.61 & 6.98 & 12.1 & 12.2 & 4.5 & 6.5 & 8.3 & 7.75 \\
\hline $\mathrm{Cr}_{\mathrm{I}}$ & 524 & 444 & 1200 & 1190 & 270 & 370 & 680 & 603 \\
\hline $\mathrm{Co}$ & 21.8 & 9.8 & 61.2 & 44.1 & 6.8 & 6.4 & 14.5 & 22.0 \\
\hline $\mathrm{Ni}$ & 296 & 94 & 990 & 650 & 32 & 37 & 134 & 295 \\
\hline $\mathrm{Ba}$ & 118 & 63 & 345 & 277 & 32 & 42 & 26 & 41 \\
\hline La & 11.2 & 4.20 & 35.9 & 27.6 & 1.89 & 1.83 & 1.26 & 3.35 \\
\hline $\mathrm{Sm}$ & 5.10 & 1.90 & 16.4 & 12.7 & 0.80 & 0.80 & 0.62 & 1.62 \\
\hline Eu & 1.21 & 1.18 & 1.65 & 1.51 & 1.05 & 1.14 & 0.93 & 0.83 \\
\hline $\mathrm{Yb}$ & 3.49 & 1.63 & 11.1 & 8.86 & 0.60 & 0.90 & 0.60 & 1.21 \\
\hline I.u & 0.49 & 0.23 & 1.50 & 1.20 & 0.107 & 0.129 & 0.09 & 0.17 \\
\hline Th & 1.76 & 0.67 & 5.7 & 4.4 & 0.26 & 0.29 & 0.21 & 0.52 \\
\hline$M g^{\prime}$ & 70 & 67 & 70.4 & 72.0 & 693 & 65.3 & 68.7 & 64.5 \\
\hline
\end{tabular}

$\mathrm{Mg}_{\mathrm{g}}=$ hulk $\left.\mathrm{mol} \% \mathrm{Mg} / \mathrm{Mg}+\mathrm{Fc}\right) . \quad 1$ = Mean of 10 bulk samples of $\mathrm{ARH}$ (Mckay et al, 1986; Simon et al., 1988: Wanke et at. 1974, 1975). $2=$ Mean of FFB samples 67015,67016, 67035, and 67915 (1.aul and Schmitt, 1973: Wänke ef al, 1975, 1976, Wasson ef at, 1977, Marvin and Lindstrom, 1983; Lindstrom and Salpas, 1981). 3-Fstimated mean composition of the MIMB (mafic impact-melt breceia) component of the ARI3s. based on the observed distribution of MIMB clasts ( $\mathrm{Fig} / \mathrm{b}$ ). The composition is a mixture of $66 \%$ group $2 \mathrm{DB}, 17 \%$ group $1 \mathrm{~F}$, and $17 \%$ group $1 \mathrm{M}$. (compositions from Korotev, 1994). This mixture, when mixed with the prebasin regolith of column 5 and an FeNi metal component in the proportions 93:7.3:-1.3, approximates well the average composition of the MIMB clasts (Table 2, column 5). This implies that the MIMB "clast" samples contain $-7 \%$ feldspathic matrix, on average. 4 = Estimated average composition of the MIMB component of the FFFBs (group 2NR of Korotev, 1994). 5 = Composition of the prebasin components of the ARl3s estimated from mass balance: $C_{5}-\left(C_{1}-f C_{3}\right)(\mathrm{l}-f)$, where $\left(C^{2}\right.$ equals concentration. the subscript is the column number, and $f$ is the fraction of MIMI3. For this calculation. $f=01275$, which is the value reguired to vield a Sin concentration of $0.80 \mu \mathrm{g} / \mathrm{g}$, see text. $6=$ Composition of the prehasin components of the FFBs estimated from mass balance: $C_{6}=\left(C_{2}-f\left(C_{4}\right) /(1-f)\right.$. For this calculation, $f=0.092$, which is the value required to yicld a sin concentration of $0.80 \mu \mathrm{g} / \mathrm{g}$ : see text. $7-1$ unar meteorite Yamato-86032: mean based on data of Koeberl et at. $(1989,1990)$. Warren and Kallemeyn (109)1). and this lab. 8 = L.unar meterite (U1593069 (Korotevet al, 1995, and updated data). 
If we assume that the ARBs are simple binary mixtures of components representing (1) a well-mixed prebasin regolith (PBR) and (2) clasts of mafic impact-melt breccias (MIMBs), we can estimate the average concentrations of other elements in the prebasin regolith by simple mass balance. For any element,

$$
C_{\mathrm{ARB}} \text { or } C_{\mathrm{FFB}}=f C_{\mathrm{M} I \mathrm{MB}}+(1-f) C_{\mathrm{PBR}}
$$

where $C$ is the average concentration of the element in the three components and $f$ is the average mass fraction of MIMB component. Average concentrations of some key major and trace elements in ARBs $\left(C_{A R B}\right)$ are given in column 1 of Table 3 and estimates of $C_{\text {MIMB }}$ are given in column 3 . The $C_{\text {MIMB }}$ values were obtained by assuming that a single mafic-melt breccia component is appropriate and that its composition is represented by linearly combining the compositions of groups 2DB, 1M, and IF (from Korotev, 1994) in the proportions observed for the analyzed clast samples (i.e., $66 \%$ 2DB, $17 \% 1 \mathrm{M}$, and $17 \% \mathrm{lF}$ ).

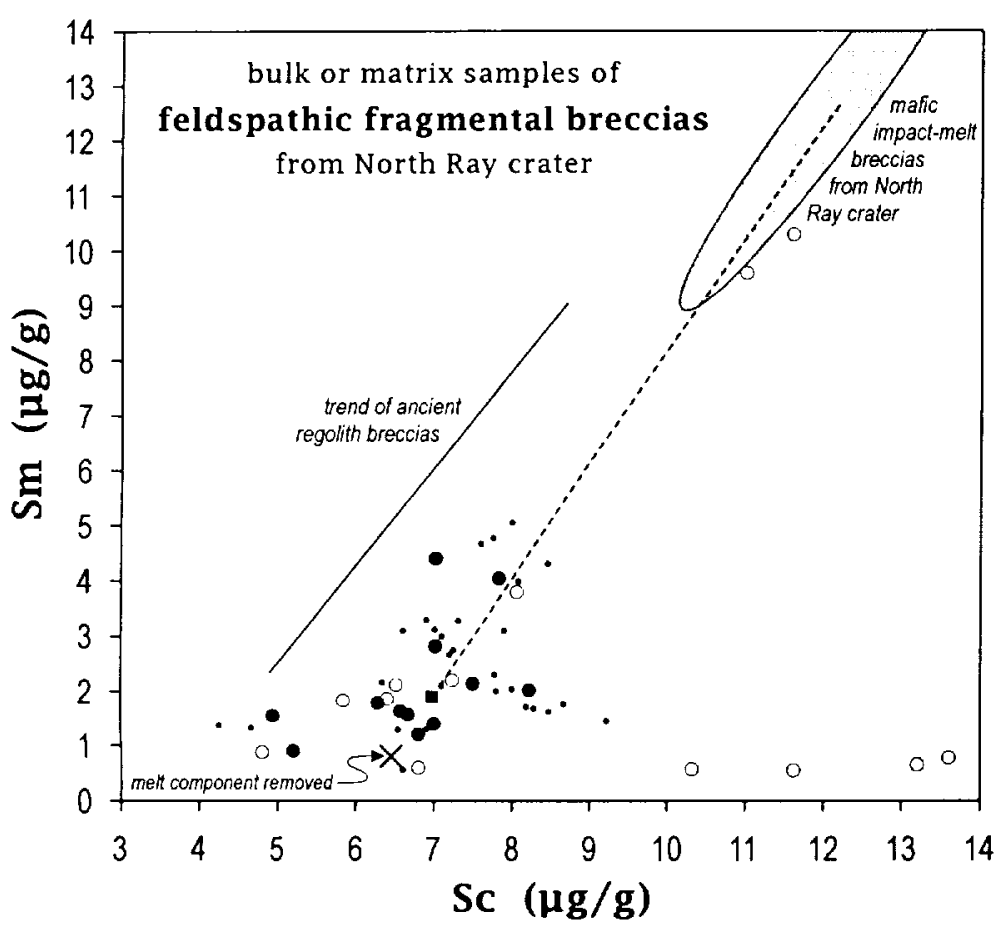

FiG. 2. Sc and $\mathrm{Sm}$ concentrations in "bulk" or "matrix" subsamples of feldspathic fragmental breccias (FFBs, large circles) and soils ( $<1 \mathrm{~mm}$ fines; small circles) from station 11 at North Ray crater. Solid large circles are subsamples of FFBs of intermediate $\mathrm{Mg}^{\prime}$ (sample means of 65-68) from which the mean composition of Table 3 was calculated (solid square); open circles are from FFBs of more extreme $\mathrm{Mg}^{\prime}$. As with Apollo 16 granulitic breccias, there is a tendency for Sc concentrations to increase with decreasing $\mathrm{Mg}^{\prime}$ (Lindstrom and Lindstrom, 1986). For the four samples with $>10$ $\mu \mathrm{g} / \mathrm{g} \mathrm{Sc}, M g$ ' is $<58$ (67455 and subsamples of 67513). The field of "mafic impact-melt breccias from North Ray crater" is defined by samples of Fig. 3 ("group-2NR melt breccias") and the melt breccias from North Ray crater of Fig. 17 of Korotev (1994). The dashed line, which is the same as that of Fig. 3, illustrates the mixing trend between the bulk samples and the mafic impact-melt breccias. This trend is similar to that of the ARBs (solid line, from lig. I) but runs parallel to it, at higher $\mathrm{Sc}$ concentration, because both the Sm-poor and Sm-rich components of the FFBs have greater Sc concentrations than the corresponding components of the ARBs. The $X$ represents the estimated average composition of the residual prebasin components of the FFBs (Table 3, column 6) after removal of the melt breccia component from the mean composition of the typical FFBs (solid square). The two open circles with $-10 \mu \mathrm{g} / \mathrm{g} \mathrm{Sm}$ are subsamples of 67435, which is classified as an FFB (Stöffler et al, 1985) but is an unusually mafic sample that contains a large melt-breccia component (Warner ef al, 1976). See Fig. 3 for other sources of data.
The value $f$ can be obtained from Eq. (1) by assuming that $C_{\mathrm{PBR}, \mathrm{Sn}}$ is $0.80 \mu \mathrm{g} / \mathrm{g}$, as estimated above from Fig. 1. This leads to value of $27.5 \%$ for $f$, and using this value, $C_{\mathrm{PBR}}$ for other elements an be calculated (Table 3, column 5). For example, the Sc f the $\mathrm{Sm}$-poor clasts $(4.8 \mu \mathrm{g}$. Table 2, column 4$)$. For incomp tible elements, values of $C_{\mathrm{PBR}}$ calculated from Eq. (1) are very e to the value selected for $f$. The observed scatter in ITE cly narrow range. At $C_{\mathrm{PBR}, \mathrm{Sc}}=4 \mu \mathrm{g} / \mathrm{g}, C_{\mathrm{PBR} . \mathrm{Sm}}$ lies between $\mu \mathrm{g} / \mathrm{g}$ and $1.04 \mu \mathrm{g} / \mathrm{g}(95 \%$ confidence limits, Fig. $1 \mathrm{a})$, limiting alues. The range of compositions of the small matrix subsample of $A R B$ in Fig. la corresponds to mixtures containing between $10 \%$ and $50 \%$ mean MIMB component. Because the average composition of the estimated prebasin regolith is similar to the average ition of the Sm-poor clasts, the distribution of Sm-poor clasts in Fig. Ib probably represents the distribution of lithologies in the prebasin regolith, i.e., it consisted mainly of feldspathic components, $<5 \mu \mathrm{g} / \mathrm{g}$ Sc, with a minor abundance of mafic components, $>10 \mu \mathrm{g} / \mathrm{g} \mathrm{Sc}$.

\section{Compositional Comparison of Ancient Regolith Breccias and Feldspathic Fragmental Breccias}

Subsamples of FFBs from North Ray crater described as "bulk" or "matrix" are more variable in composition than similar subsamples of ARBs, and the variability is not as systematic as it is for the ARBs (Fig. 2). In addition to variability in ITE concentrations, $M g^{\prime}$ values are highly variable in FFBs, ranging from -52 in 67513,7008 and 67513,7024 (Jolliff and Haskin, 1995) to -78 in 67915 and 67955 (Lindstrom and Salpas, 1981); this compares with a narrower range of 66 to 72 among bulk samples of ARBs (references of Fig. 1a). For the FFBs, intermediate values are most common, however, and the mean of Table 3 (column 2) is based on multiple subsamples of four FFBs with $\mathrm{Mg}^{\prime}$ between 65 and 68 . This same compositional variability, but to a lesser extent, is seen in fines from station 11 at North Ray crater (Table 4; Fig. 2) because the fines are primarily disaggregated and mixed FFBs (mean $M g^{\prime}=67$; Table 4).

To a first approximation, ARBs and FFBs are similar in bulk composition (Table 3). Like the ARBs, the FFBs contain both Sm-poor prebasin lithologies and Sm-rich, mafic impact-melt breccias (Lindstrom and Salpas, 1981, 1983; Norman, 1981; Marvin and Lindstrom, 1983; Stöffler et al., 1985). Thus, clasts (and other subsamples) from FFBs form two trends (Fig. 3) qualitatively similar to those of the clasts from the ARBs (Fig. 1b). However, some important compositional differences exist.

Samarium-rich components-A significant distinction is that the clasts of mafic impact-melt breccias in the $A R B s$ and FFBs are different. Clasts of mafic melt breccia in the ARBs correspond to compositional groups $2 \mathrm{DB}$, $1 \mathrm{M}$, and $1 \mathrm{~F}$ (Fig. 1), whereas those in the FFBs are dominated by group $2 \mathrm{NR}$, which has higher $\mathrm{Sc}$ and $\mathrm{Cr}$ concentrations than otherwise similar group 2DB (Figs. 2 and 3). Compositional group 2DB is the melt-breccia component of the Apollo 16 dimict breccias, a lithology 
TABLE 4. Average composition of soils and residual fines samples from station 11 at North Ray crater

\begin{tabular}{|c|c|c|c|c|c|c|c|c|c|c|c|c|c|c|c|}
\hline & 67011 & 67020 & 67031 & 67410 & 67450 & 67461 & 67481 & 67511 & 67601 & 67610 & 67701 & 67711 & 67941 & 67960 & mean \\
\hline $\mathrm{SiO}_{2}$ & (44.8) & (44.1) & $(45.1)$ & $(43.2)$ & $(45.8)$ & 45.2 & 44.7 & $(45.5)$ & 45.1 & $(45.1)$ & 44.3 & 44.7 & 45.8 & $(44.3)$ & 44.8 \\
\hline $\mathrm{TiO}_{2}$ & $(0.5)$ & $(0.5)$ & $(0.3)$ & $(0.35)$ & $(0.25)$ & 0.38 & 0.47 & $(0.4)$ & 0.45 & $(0.4)$ & 0.55 & 0.26 & 0.54 & 0.51 & 0.42 \\
\hline $\mathrm{Al}_{2} \mathrm{O}_{3}$ & $(28.5)$ & $(27.9)$ & $(29.6)$ & 27.6 & $(29.9)$ & 29.2 & 28.5 & 28.6 & 28.3 & $(29.9)$ & 28.6 & 29.8 & 26.2 & 26.8 & 28.5 \\
\hline $\mathrm{FeO}_{1}$ & 4.35 & 4.80 & 3.56 & 5.05 & 3.32 & 4.26 & 4.02 & 4.34 & 4.17 & 3.36 & 4.24 & 2.93 & 4.63 & 4.56 & 4.11 \\
\hline $\mathrm{MgO}$ & $(4.8)$ & $(6.0)$ & (3.8) & $(8.15)$ & (2.5) & 4.02 & 4.11 & 4.0 & 4.63 & $(3.75)$ & 4.76 & 4.12 & 6.48 & 6.9 & 4.86 \\
\hline $\mathrm{CaO}$ & 16.2 & 15.9 & 16.8 & 14.9 & 17.7 & 17.1 & 16.2 & 16.5 & 16.1 & 16.6 & 15.9 & 16.5 & 15.4 & 16.1 & 16.3 \\
\hline $\mathrm{Na}_{2} \mathrm{O}$ & 0.51 & 0.50 & 0.54 & 0.52 & 0.35 & 0.43 & 0.49 & 0.42 & 0.54 & 0.60 & 0.52 & 0.73 & 0.53 & 0.53 & 0.51 \\
\hline $\mathrm{K}_{2} \mathrm{O}$ & $(0.11)$ & $(0.10)$ & $(0.05)$ & $(0.07)$ & $(0.04)$ & 0.050 & 0.067 & $(0.06)$ & 0.077 & $(0.07)$ & 0.066 & 0.085 & 0.140 & $(0.11)$ & 0.078 \\
\hline Sc & 7.6 & 8.5 & 6.7 & 7.8 & 6.6 & 7.6 & 7.4 & 8.4 & 6.9 & 6.3 & 7.4 & 4.7 & 8.0 & 7.8 & 7.3 \\
\hline $\mathrm{Cr}$ & 590 & 690 & 430 & 820 & 370 & 500 & 520 & 520 & 540 & 440 & 580 & 400 & 680 & 620 & 550 \\
\hline $\mathrm{Co}$ & 17.1 & 23.3 & 7.8 & 30.8 & 5.0 & 11.1 & 15.2 & 11.0 & 20.1 & 10.2 & 16.4 & 9.1 & 19.1 & 16.2 & 15.2 \\
\hline $\mathrm{Ni}$ & 210 & 360 & 43 & 420 & 13 & 97 & 140 & 85 & 270 & 98 & 200 & 80 & 260 & 210 & 178 \\
\hline $\mathrm{Sr}$ & 185 & 185 & 190 & 185 & 165 & 160 & 190 & 160 & 195 & 200 & 175 & 250 & 180 & 175 & 185 \\
\hline $\mathrm{Zr}$ & 129 & 135 & 38 & 75 & 8 & 72 & 77 & 53 & 79 & 70 & 99 & 35 & 144 & 175 & 85 \\
\hline Cs & 0.12 & 0.10 & 0.05 & 0.05 & 0.06 & 0.14 & 0.06 & 0.07 & 0.07 & 0.07 & 0.09 & 0.06 & 0.13 & 0.13 & 0.09 \\
\hline $\mathrm{Ba}$ & 114 & 108 & 43 & 78 & 17 & 56 & 83 & 49 & 77 & 72 & 93 & 63 & 119 & 127 & 78 \\
\hline La & 10.1 & 9.3 & 2.70 & 4.9 & 1.02 & 4.6 & 6.2 & 3.4 & 6.1 & 4.6 & 7.5 & 3.1 & 11.2 & 10.1 & 6.1 \\
\hline $\mathrm{Ce}$ & 26.3 & 24.0 & 7.8 & 12.1 & 2.6 & 12.0 & 16.2 & 8.9 & 16.6 & 11.9 & 19.4 & 7.7 & 30.1 & 27.6 & 15.9 \\
\hline $\mathrm{Sm}$ & 4.67 & 4.30 & 1.28 & 2.30 & 0.56 & 2.03 & 2.95 & 1.67 & 2.96 & 2.16 & 3.52 & 1.32 & 5.25 & 4.77 & 2.84 \\
\hline Eu & 1.25 & 1.19 & 1.12 & 1.12 & 0.77 & 0.99 & 1.14 & 1.00 & 1.24 & 1.31 & 1.19 & 1.67 & 1.23 & 1.25 & 1.18 \\
\hline Tb & 0.96 & 0.90 & 0.26 & 0.52 & 0.13 & 0.43 & 0.59 & 0.36 & 0.63 & 0.46 & 0.70 & 0.25 & 0.99 & 1.04 & 0.59 \\
\hline Yb & 3.4 & 3 & 1.14 & 2.00 & 0.50 & 1.61 & 11 & 1.33 & 2.3 & 1 & 2.56 & 1.10 & & 3.5 & 2.1 \\
\hline Lu & 0.46 & 0.45 & 0.186 & 0.286 & 0.074 & 0.21 & 0.277 & 0.186 & 0.35 & 0.227 & 0.35 & 0.147 & 0.52 & 0.52 & 0.30 \\
\hline $\mathrm{Hf}$ & 3.5 & & 1.01 & & & 1.42 & 1.95 & & 2.19 & 1.63 & 2.37 & 0.88 & 3.7 & 3.8 & 2.1 \\
\hline $\mathrm{Ta}$ & 0.41 & 0.39 & 0.13 & 0.24 & 0.04 & 0.22 & 0.28 & 0.17 & 0.29 & 0.25 & 0.30 & 0.13 & 0.44 & 0.53 & 0.27 \\
\hline Th & 1.62 & 1.54 & 0.46 & 1.03 & 0.12 & 0.70 & 0.97 & 0.53 & 1.04 & 0.74 & 1.22 & 0.53 & 1.90 & 1.88 & 1.02 \\
\hline $\mathrm{U}$ & 0.48 & 0.53 & 0.13 & 0.30 & 0.03 & 0.19 & 0.27 & 0.15 & 0.28 & 0.22 & 0.43 & 0.20 & 0.61 & 0.51 & 0.31 \\
\hline $\mathrm{Mg}^{\circ}$ & $(66)$ & $(69)$ & $(65.5)$ & (74) & $(57)$ & 62.7 & 64.6 & 62.2 & 66.5 & $(66.5)$ & 66.7 & 71.5 & 71.4 & 73.0 & 66.9 \\
\hline
\end{tabular}

Values in $\mu \mathrm{g} / \mathrm{g}$, except oxides and $\mathrm{Mg}^{\prime}$ in mass percent. $\mathrm{FeO}_{\mathrm{t}}=$ total $\mathrm{Fe}$ as $\mathrm{FeO} ; \mathrm{Mg}^{\prime}=$ bulk mol\% $\mathrm{Mg} /(\mathrm{Mg}+\mathrm{Fe})$. Sample numbers in italics are not true soils but residual fines samples from collection bags for rocks with the corresponding $67 \times x 5$ sample number, except that 67610 accompanied rake sample 67600 (Ulrich, 1981). No data are available for concentration values in parentheses; the values are estimates based on the accompanying rock and other similar FFB samples: $\mathrm{Al}_{2} \mathrm{O}_{3}$ estimated from anticorrelation with $\mathrm{FeO} ; \mathrm{MgO}$ calculated to give the same value of $\mathrm{Mg}^{\prime}$; ' $\mathrm{TiO}_{2}$ estimated from $\mathrm{Al}_{2} \mathrm{O}_{3}$ and $\mathrm{FeO}_{2} \mathrm{~K}_{2} \mathrm{O}$ estimated from weak correlation with ITEs; $\mathrm{SiO}_{2}$ estimated from closure. Data compiled and averaged from LSPET (1973). Duncan et al. (1973), Haskin et al. (1973), Simkin et al. (1973), Taylor et al. (1973), Wänke et al. (1973), Fruchter et al. (1974), Rose et al (1975), Rhodes et al (1975), Boynton et al. (1975, 1976), Laul and Papike (1980), Korotev (1982), Jolliff and Haskin (1995), and this work.

not found at North Ray crater (James et al., 1984; McKinley et al., 1984). Compositional group 1 is characteristic of stations of the Cayley plains and is rare to absent at station 11 on the edge of North Ray crater, although some samples were found at station $13,-1 \mathrm{~km}$ from the crater. In contrast, most samples of compositional group 2NR were found at North Ray crater (Korotev, 1994).

As with the ARBs, we can estimate the average composition of the prebasin components of the FFBs by subtracting the average composition of group-2NR impact-melt breccias (Table 3, column 4) from the average composition of the FFBs (column 2) using Eq. (1). Again, however, we are faced with the question of how much to subtract, i.e., the magnitude of $f$. From the distribution of Smpoor points on Fig. 3, it is unlikely that the Sm concentration of the prebasin portion of the FFBs is $<0.2 \mu \mathrm{g} / \mathrm{g}$ (i.e., $f<13.5 \%$ ) or $>\sim 1.2$ $\mu \mathrm{g} / \mathrm{g}(f>6 \%)$. Because, like the ITEs, siderophile elements are carried in large part by the component of mafic melt breccia, siderophile-element concentrations also help constrain the value of $f$. It is unlikely that the average Ni concentration of the prebasin components is $<20 \mu \mathrm{g} / \mathrm{g}$ (i.e., $f<12 \%$ ) because this is the lowest value observed among granulitic breccias from North Ray crater, a principle component of the FFBs. It is also probably not $>\sim 70 \mu \mathrm{g} / \mathrm{g}$ $(f>4 \%$ ), which is the mean for the soils with the lowest $\mathrm{Sm}$ concentrations (Table 4). Thus, the FFBs probably contain between
$6 \%$ and $12 \%$ MIMB component. For convenience in comparison, I assume that the average $\mathrm{Sm}$ concentration of the prebasin components of the FFBs $\left(\mathrm{C}_{\mathrm{PBC}}\right)$ is $0.80 \mu \mathrm{g} / \mathrm{g}$, the same as that for the ARBs. This leads to $f=9.2 \%$; using this value, concentrations of other elements in the average prebasin components of the FFBs can be calculated from Eq. (1) (Table 3, column 6).

The FFBs contain a lower average abundance of mafic impactmelt breccias $(9.2 \%)$ than the ARBs $(27.5 \%)$, but the variation among different FFB samples is large, ranging from essentially zero to $-25 \%$ (and $>80 \%$ for anomalous sample 67435 ; Fig. 2 ). This observation is consistent with the petrographic data of Stöffler et al. (1985), who noted that the average abundance of mafic melt breccias (intergranular, micropoikilitic, subophitic-ophitic-intersertal) was $\sim 5 \%$, but ranged up to $-20 \%$ among different samples of FFB. Note that of the first two samples of Table 7 of Stöffler et al. (1985), the only two samples from station 13, are those classified as ARBs by McKay et al. (1986).

Samarium-poor components-Several significant differences also exist between the average compositions of the Sm-poor components of the FFBs and ARBs (Table 3, columns 5 and 6). First, the Sm-poor components of the FFBs are slightly more mafic, being richer in $\mathrm{Fe}, \mathrm{Mg}, \mathrm{Sc}$, and $\mathrm{Cr}$ and poorer in $\mathrm{Al}_{2} \mathrm{O}_{3}$ and $\mathrm{CaO}$. Second, the ratio of concentrations of heavy rare earth elements 
(REEs) to light REEs is slightly greater for the prebasin components of the FFBs (Fig. 4), a characteristic consistent with the greater abundance of mafic minerals. Third, the Sm-poor components of the FFBs have a lower average value of $\mathrm{Mg}^{\cdot}(65 \mathrm{vs} .69)$. As noted above, FFBs are highly variable in $\mathrm{Mg}^{\prime}$; but for the average composition of Table 3 , very-low- $\mathrm{Mg}^{\prime}$ samples were excluded (i.e., 67455 and subsamples from 67513; Lindstrom and Salpas, 1981; Jollift and Haskin, 1995). Thus, this difference in averages probably indicates a fundamental difference between the suites of igneous precursors of the two types of breccia. No reasonable component can be added in small proportions to the mean composition of the prebasin components of the FFBs to yield the mean composition of the prebasin components of the ARBs. The higher $\mathrm{Mg}^{\prime}$ of the $A R B$ s is also not casily attributable to the high- $\mathrm{Mg}^{\prime}$ glasses described by Wentworth and McKay (1988b) because $\mathrm{Mg}$ concentrations are similar in the prebasin components of the two breccia types and $\mathrm{Fe}$ concentrations are lower in the ARBs. Finally, the prebasin components of the FFBs have greater concentrations of $\mathrm{Na}$ and $\mathrm{Eu}$ than those of the $A \mathrm{RBS}$, which indicates that the plagioclase is more albitic, on average, in the FFBs. The difference corresponds only to an $\sim 0.8 \mathrm{~mol} \%$ albite component in the plagioclase, but on the Moon, this is significant. At the Apollo 16 site, anorthosite with plagioclase more sodic than that typical of ferroan anorthosite appears to be restricted to some North Ray crater FFBs (Korotev, 1983; James et al., 1989; Norman et al., 1991).

\section{DISCUSSION}

\section{Ancient Regolith Breccias from Feldspathic Fragmental Breccias}

The various observations discussed above suggest that the ARBs and FFBs represent two different populations of lithologies (Table 5). I have experimented with the suggestion of Takeda et al. (1990) that addition of components to the FFBs might account for the ARBs. $\Lambda$ reasonably good fit to the mean composition of the ARBs can be obtained, for example, by mixing $45 \%$ average $F F B$, $28 \%$ group-2DB, $2.8 \%$ group-1 impact-melt breccias, and $24 \%$ plagioclase, such as that found in ferroan anorthosite. This exercise demonstrates that if FFBS such as those that occur at North Ray crater are precursors to the ARBs, a large volume of other components must have been added to the regolith in order to account for the differences in composition. Thus, it is unlikely that the glass components present in the ARBs but absent in the FFBs can by themselves account for the compositional differences.

The Apollo 16 site was selected in order that two landforms could be sampled, the Cayley plains and the Descartes Formation (Muehlberger et al, 1980). The compositional differences between the prebasin components of the $A R B S$ and the FFBs are almost certainly a consequence of the Cayley-Descartes dichotomy. The FFBs are the most characteristic component of North Ray crater ejecta (Stöffler et al., 1985), yet they are unusual on the Cayley plains stations (i.e., the central and southern stations of the Apollo 16 site). Also, the few samples that do occur (e.g., 60075) may be, in fact, ejecta from North Ray crater, and several of the feldspathic "fragmental polymict breccias" of Ryder and Norman (1980) are actually regolith breccias (e.g. Mckay et al., 1986). Most ARBs, on the other hand, were found at central and southern stations; none were found at stations II

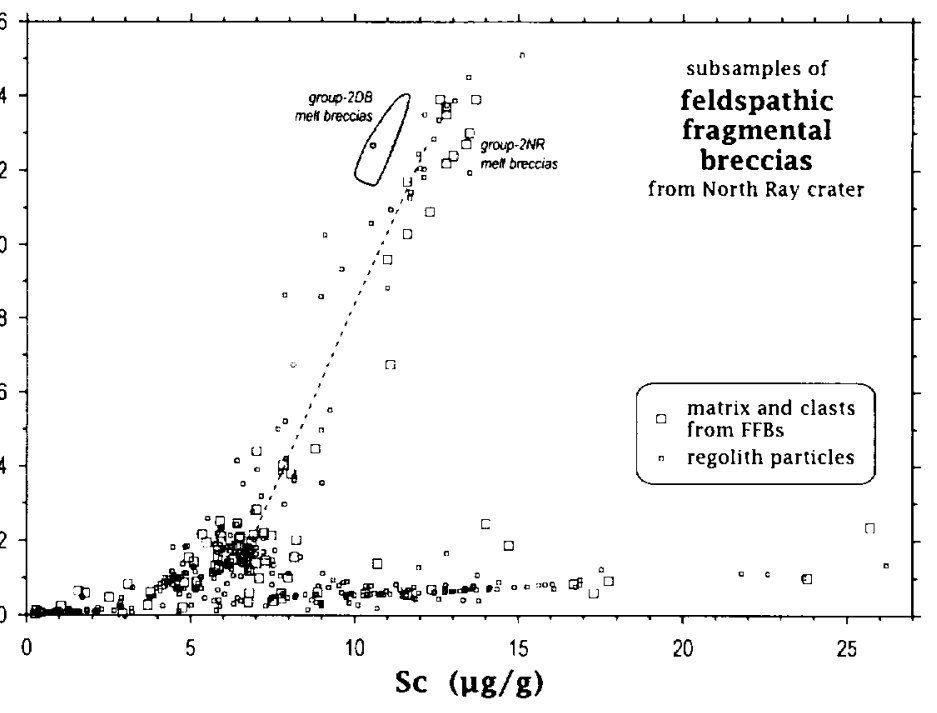

G 3. Sc and $\mathrm{Sm}$ concentrations in subsamples of FFBs and $1-4 \mathrm{~mm}$ regolith particles Ray crater. The particles (from samples 67513, 67703, 67712, and 67713) defined by the clasts from the $A$ RBs (Fig. lb). Most of the mafic inpact-melt North Ray crater samples belong to compositional oroup 2NR which has ayley plains (Korotev, 1994). The dashed line segment is a mixing line defined by the 1983), Wänke et al. (1973, 1975, 1976), Warner et al. (1976), Warren and Wasson 1978), Wasson et al (1977), Jolliff and Haskin (1995), and this work. For clarity, data on the edge of North Ray crater and only two were found at nearby station 13 (McKay et al., 1986). Thus, the ARBs are not ejecta from North Ray crater but are a component of the regolith of the Cayley plains. The Cayley plains were probably produced by the Imbrium impact (Oberbeck, 1975; Hodges and Muehlberger, 1981; Spudis, 1984), and it is likely that at least some of the components of the ancient regolith, which is represented by the $A R B s$, have a provenance, northwest of the site, toward the Imbrium basin. In contrast, the Sm-poor components of the North Ray crater ejecta are thought to derive from beneath the blanket of Cayley debris in the Descartes Formation (Norman, 1981; Stöffler et al, 1985), which is probably Nectaris ejecta (Stöffler et al., 1985). Thus, although it is reasonable that the Apollo 16 ARBs had some type of fragmental breccia as a precursor, it is unlikely that the FFBs of the Descartes Formation, as represented in the North Ray crater ejecta, are a significant component of the ARBs.

\section{The Prebasin Crust in the Central Highlands}

In those regions of the highlands most distant from basins, remote mineralogical and geochemical techniques show that the lunar surface is feldspathic, i.e. concentrations of $\mathrm{Fe}$ and $\mathrm{Mg}$ are low and, by inference, concentrations of $\mathrm{Al}$ and $\mathrm{Ca}$ are high (Biclefeld et al. 1976; Davis, 1980; Korotev et al., 1980; Lucey et al., 1995; Fischer and Picters, 1995). This observation is confirmed by the feldspathic lunar meteorites, which provide independent estimates of the composition of the lunar crust (e.g., Palme et al., 1991). All of the lunar meteorites that are relatively free of mare-derived and KREEP components are highly feldspathic (i.e., normative feldspar abundances range from 


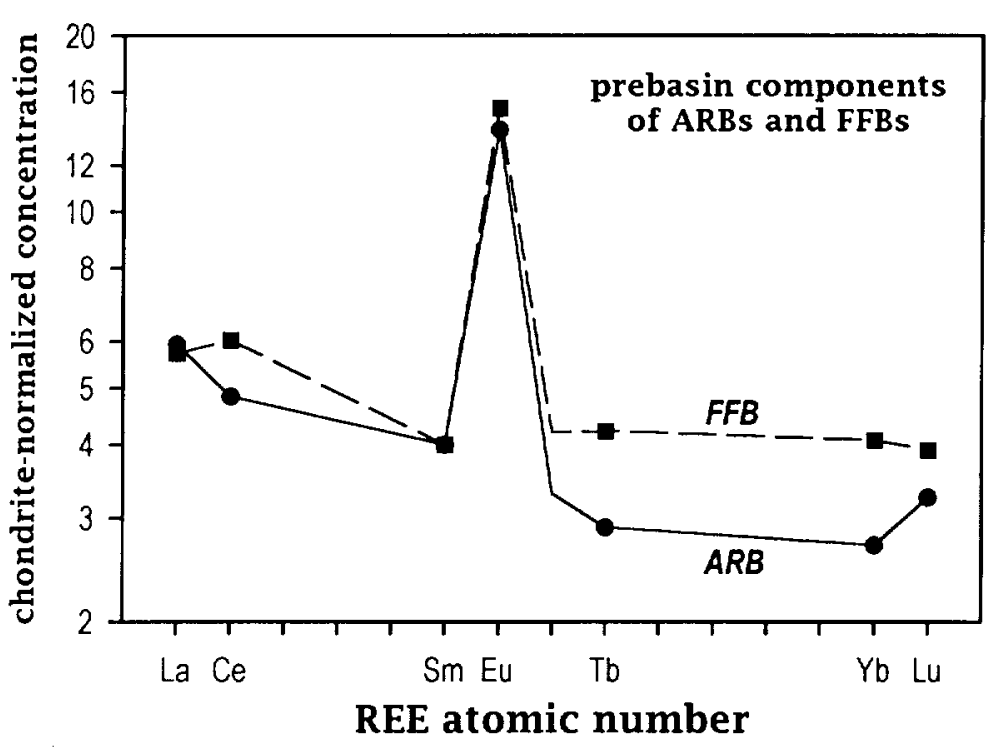

FIG. 4. Chondrite-normalized concentrations of REEs (rare earth elements) in the estimated prebasin portions of the Apollo 16 ARBs (ancient regolith breccias) and FFBs (feldspathic fragmental breccias) of North Ray crater (from Table 3). The absolute concentrations are highly sensitive to the assumed abundance of mafic impact-melt breccias $(f$ in Eq. 1). For this illustration, Sm concentrations were assumed to be 0.80 $\mu \mathrm{g} / \mathrm{g}$ for both; see text. Compared to the prebasin portion of the ARBs, that of the FFBs has a higher concentration of Eu and a greater ratio of heavy REE ( $\mathrm{Tb}, \mathrm{Yb}, \mathrm{Lu})$ to light REE (La, Ce, Sm), and this difference is not affected by any assumptions about the magnitude of $f$. The difference for $\mathrm{Ce}$ probably reflects interlaboratory biases Chondrite values: I.36x "mean Cl chondr." values of Anders and Grevesse (1989).
TABLE 5. Comparison of ancient regolith breccias and feldspathic fragmental breccias.

\begin{tabular}{|c|c|c|}
\hline & ARBs & FFBs \\
\hline $\begin{array}{l}\text { ITE-rich, mafic } \\
\text { impact-melt brec } \\
\text { abundance } \\
\text { type }\end{array}$ & $\begin{array}{l}\text { mean: } 27.5 \% \\
\text { groups } 2 \mathrm{DB} \text {, } \\
\mathrm{IM} \text {, and } 1 \mathrm{~F}\end{array}$ & $\begin{array}{l}\text { mean: } 9 \% \\
\text { group } 2 \mathrm{NR}\end{array}$ \\
\hline \multicolumn{3}{|c|}{$\begin{array}{l}\text { Sm-poor, "prebasin" } \\
\text { components }\end{array}$} \\
\hline $\begin{array}{l}\mathrm{Al}_{2} \mathrm{O}_{3} \\
\mathrm{Mg}^{\prime} \\
\text { plagioclase }\end{array}$ & $\begin{array}{l}\text { mean: } 31 \% \\
\text { mean: } 69 \% \\
\text { less sodic }\end{array}$ & $\begin{array}{l}\text { mean: } 30 \% \\
\text { mean: } 65 \% \\
\text { more sodic }\end{array}$ \\
\hline provenance & Cayley plains & $\begin{array}{l}\text { Descartes Formation } \\
\text { (North Ray crater) }\end{array}$ \\
\hline
\end{tabular}

The average $\mathrm{Mg} / \mathrm{Fe}$ ratio of the early lunar crust is an important, but unknown, petrologic parameter (e.g., Korotev et al, 1980; Korotev and Haskin, 1988; Warren, 1990). The difference in $\mathrm{Mg}^{\prime}$ between the prebasin regoliths estimated here from the ARBs and FFBs (Table 3, columns 5 and 6 ) is comparable to that between the two most feldspathic lunar meteorites (columns 7 and 8 ). Together, these differences (as well as the large range of $M g^{\prime}$ observed among different samples of Apollo 16 $\mathrm{FFBs}$ ) demonstrate that regional variation in $\mathrm{Mg} / \mathrm{Fe}$ ratio was an important feature of the early lunar crust.

\section{SUMMARY AND CONCLUSIONS}

$\sim 70-80 \%$ by mass). Compared to estimates of the composition of the average or typical lunar highlands crust that are based on orbital data and feldspathic lunar meteorites, the regolith presently at the surface of the Apollo 16 site is not typical but is more mafic (greater $\mathrm{Fe}$ and $\mathrm{Mg}$ ) and richer in ITEs (Korotev et al., 1980; Korotev and Haskin, 1988; Warren and Kallemeyn, 1991; Lucey et al., 1995). These differences are directly attributable to the high abundance $(-30 \%)$ of KREEP-bearing, mafic impact-melt breccias in the regolith of the Cayley plains (Morris et al., 1986; Korotev, 1996), a component that is absent from the feldspathic lunar meteorites and, by definition, the "prebasin" components of the Apollo 16 ARBs and FFBs.

Assuming that fragmental breccias represent a regolith or megaregolith with little or no surface exposure, the analysis presented here shows that when the basin components are removed from the regolith of the Descartes Formation and the ancient regolith of the Cayley plains source area, the residual regoliths are compositionally similar to those represented by the feldspathic lunar meteorites. The most significant difference is that the prebasin regoliths estimated for both the Cayley (ARB) and Descartes (FFB) Formations are compositionally more feldspathic $\left(30-31 \% \mathrm{Al}_{2} \mathrm{O}_{3}, 4.5-6.5\right.$ $\mu \mathrm{g} / \mathrm{g} \mathrm{Sc}$ ) than even the most feldspathic meteorites $\left(28-29 \% \mathrm{Al}_{2} \mathrm{O}_{3}\right.$, $\sim 8 \mu \mathrm{g} / \mathrm{g} \mathrm{Sc}$; Table 3, Fig. Ib). The prebasin components are dominated by feldspathic granulitic breccias (typically $24-33 \% \mathrm{Al}_{2} \mathrm{O}_{3}$ ), feldspathic impact-melt breccias (typically $26-33 \% \quad \mathrm{Al}_{2} \mathrm{O}_{3}$ ), and cataclastic anorthosites $\left(32-36 \% \mathrm{Al}_{2} \mathrm{O}_{3}\right)$ (e.g., Lindstrom and Salpas, 1983; Stöftler et al, 1985; Simon et al., 1988). Thus, the high alumina concentrations estimated here for the Apollo 16 prebasin regoliths suggest that the abundance of highly feldspathic anorthosite $\left(\mathrm{Al}_{2} \mathrm{O}_{3}>32 \%\right)$ was greater in regoliths of the early Central Highlands than it is in the source region of any of the lunar meteorites 1986) are a component of the Cayley plains. In contrast, the feldspathic fragmental breccias (FFBs) that are prevalent in the ejecta of North Ray crater are believed to represent the Descartes Formation (e.g., Norman, 1981; Stöfler et al., 1985). The two types of breccia are similar in that they are composed largely of rock and mineral fragments. However, the constituent rock types of the two types of breccia differ, and these differences probably reflect the CayleyDescartes dichotomy. On average, ARBs contain $27.5 \%$ clasts of mafic impact-melt breccia of compositional groups $2 \mathrm{DB}, 1 \mathrm{M}$, and $1 \mathrm{~F}$; this basin-era component probably originates mainly from beneath the upper crust. The remaining material is a suite of rock types of the early upper crust and their brecciated derivatives that is highly feldspathic $\left(31 \% \mathrm{Al}_{2} \mathrm{O}_{3}\right)$ and poor in incompatible trace elements. In contrast, the FFBs of North Ray crater contain an average of $\sim 9 \%$ clasts of mafic impact-melt breccia, and these clasts are of a different compositional group, group $2 \mathrm{NR}$. The prebasin components of the FFBs are also highly feldspathic and poor in incompatible trace elements but differ from the prebasin components of the ARBs in that they are more ferroan $\left(\mathrm{Mg}^{\prime}=65 \mathrm{vs}, 69\right)$, slightly less feldspathic $(30 \%$ $\mathrm{Al}_{2} \mathrm{O}_{3}$ ), relatively richer in heavy rare earth elements, and somewhat more albitic, on average. Together, these observations make it unlikely that the ARBs of the Cayley plains were derived from the FFBs of Descartes Formation by any simple evolutionary process, as suggested by Takeda et al. (1990).

Compositions estimated here for the prebasin components of the Apollo 16 ARBs and FFBs are similar to highlands regoliths from parts of the Moon that are distant from major mare-filled basins, as represented by the feldspathic lunar meteorites, in that they are highly feldspathic and poor in incompatible trace elements. However, the
The ancient regolith breccias (ARBs) of Apollo 16 (McKay et al., 
Apollo 16 prebasin materials are somewhat more feldspathic $(30-31 \%$ $\left.\mathrm{Al}_{2} \mathrm{O}_{3}\right)$ than any of the feldspathic lunar meteorites $\left(26-29 \% \mathrm{Al}_{2} \mathrm{O}_{3}\right)$, implying that the early central nearside of the Moon may have been atypically rich in plagioclase. The difference in $\mathrm{Mg}^{\prime}$ between the prebasin portions of the $\Lambda$ RBs (69) and FFBs (65) represents lateral variation in the $\mathrm{Mg} / \mathrm{Fe}$ ratio of the feldspathic crust on a scale smaller than the Central Highlands. The high abundance $(-30 \%)$ of mafic impact-melt breccias in the present regolith of the Cayley plains (compared to regoliths represented by the feldspathic lunar meteorites) is the cause of the relatively high surface concentrations of elements carried by mafic minerals ( $\mathrm{Fe}, \mathrm{Mg}$. Sc, $\mathrm{Cr}$ ) as well as elements associated with KREEP (e.g., K. Sm, Th).

It is reasonable to ask how the composition of the feldspathic prebasin portions of present regolith of the Cayley plains, as sampled at the central and southern stations of the Apollo 16 site, compares with those inferred here for the ARBs and FFBs. Addressing this question is complicated because the present regolith contains a number of syn- and postbasin components in addition to mafic impact-melt breccias, namely, meteoritic material accumulated since basin formation and glasses and crystalline basalts from the maria. I defer a complete discussion of the components of the present regolith to a subsequent paper. However, preliminary modeling indicates that if the mafic impact-melt breccias, mare-derived components, and post-basin meteoritic materials are "removed" from the present regolith of the Cayley plains, the composition of the residual feldspathic material is more similar to that estimated here for the prebasin portion of the $A$ RBs than the prebasin portion of the FFBs (Korotev, 1996). This observation is consistent with the paucity of FFBs (and melt breccias of group-2NR composition) in the present Cayley regolith.

If the materials excavated at North Ray crater are primarily of the Descartes Formation, and if, as argued here, FFBs such as those sampled at North Ray crater are not a volumetrically important component of the regolith of the Cayley plains (of the ancient component, at least), then the Cayley regolith in the vicinity of the Apollo 16 site appears to contain little reworked material from the underlying Descartes Formation. If the supposition could be confirmed, it would provide an important constraint on models of the history of the Apollo 16 site and distribution of basin cjecta, as some models require that the Cayley plains contain a large fraction of pre-lmbrium local substrate that was mixed and redistributed by Imbrium ejecta (Oberbeck, 1975; Spudis, 1984). What, then, is the source of the feldspathic matcrials if the Cayley regolith at the Apollo 16 site actually contains little pre-Imbrium material local to the site? Niternatively, if much of the feldspathic material presently in the Cayley regolith of the Apollo 16 site is, in fact, of local origin, then the ejecta of North Ray crater cannot be typical of the pre-lmbrium substrate. Infortunately, there is little known of the feldspathic components of the Cayley plains other than that such materials include highly feldspathic anorthosites, such as samples 60015,62275 , and those associated with the dimict breccias (e.g. 61015). Resolution of these questions could be addressed by a systematic study of the feldspathic materials in $1-10 \mathrm{~cm}$ grain-size fractions of regolith from the Cayley plains and comparison to the well-studied feldspathic materials of North Ray crater.

Acknowledgments-I thank Kaylynn Rockow and Brad Jolliff for help in sample analysis and thin-section preparation and Marilyn Lindstrom and Mare Norman for their consiructive reviews. This work was supported by the National Aeronautics and Space Administration through grant NAGW3343 to L. A. Haskin.

Editorial handling: K. Keil

\section{REFERENCES}

ANDERS E. AND GREVESSE N. (1989) Abundances of the elements: Meteoritic and solar. Geochim. Cosmochim. Acta 53, 197-214.

BIELFFELD M. J., REEDY R. C., METZGER A l., TROMBBKA I. I. AND ARNOLD J. R. (1976) Surface chemistry of selected lunar regions. Proc. Lunar Sci Conf. 7th, 2661-2676.

BOYNTON W. V., BAEDECKER P. A., CHOL C.-L., ROBINSON K. L. AND WASSON J. T. (1975) Mixing and transport of lunar surface materials: Evidence obtained by the determination of lithophile, siderophile, and volatile elements. Proc. Lunar Sci. Conf. 6th, 2241-2259.

BOYNTON W V CHOU $C-L$. ROBINSON K. I., WARRI:N P. H. ANI WASsON J. T. (1976) L ithophiles, siderophiles, and volatiles in Apollo 16 soils and rocks. Proc. Lunar Sci. Conf. 7th, 727-742.

DAvis P. A., JR. (1980) Iron and titanium distributions on the moon from orbital gamma ray spectrometry with implications for crustal evolutionary models, $J$. Geophys. Res. 85, 3209-3224.

DUNCAN A. R., ERLANK A. J., Willis J. P. AND AHRENS L. H. (1973) Composition and inter-relationships of some Apollo 16 samples. Proc. Lunar Sci. Conf. 4th, 1097-1113.

FisciIER E. M. AND PIETFRS C. M. (1995) Lunar surface aluminum and iron concentrations from Galileo solid state imaging data, and mixing of mare and highland materials. J. Geophys. Res. 100, 23.279-23.290.

Frucliter J. S., KRIDELBAUGH S. J., ROBYN M. A. ANI) (iolites (i. G (1974) Breccia 66055 and related clastic materials from the Descartes region, Apollo 16. Proc. Lunar Sci. Conf. 5th, 1035-1046

IIASKIN I. A., IFIMKE P. A., BIANCHARD D. P., JACOBS J. W. AND TELANDER K. (1973) Major and trace element abundances in samples from the lunar highlands. Proc. Lunar Sci. Conf. 4th, 1275-1296

HODGES C. A. ANDD MUEHLBERGER W. R. (1981) K. Summary and critique of geologic hypotheses. In Geology of the Apollo 16 Area. Central Lunar Highlands (eds. G. I. Ulrich et al.). pp. 215-230. (I. S. Gcol. Surv. Prof. Paper 1048.

JAMES O. B. (1981) Petrologic and age relations of the Apollo 16 rocks: Implications for the subsurface geology and age of the Nectaris basin Proc. Lunar Planet. Sci. Conf. 12th, 209-233.

JAMES O. B., FloHR M. K. AND L.INDSTROM M. M. (1984) Petrology and geochemistry of lunar dimict breccia 61015. Proc. L.unar Planet. Sct Conf. 15th, C63-C 86 .

JAMES O. B., LiNDSTROM M. M. AND Flohr M. K. (1989) Ferroan anorthosite from lunar breccia 64435: Implications for the origin and history of lunar ferroan anorthosites. Proc. Lumar Plamet. Sci Conf 19th, 219-243.

JeRDE E A WARREN P. H.. MORRIS R. V.. HEIKEN G. HI. ANI) VANIMAN D. T. (1987) A potpourri of regolith breccias: "New sampies" from the Apollo 14, 16, and 17 landing sites. Proc. Lunar Planet. Sci. C'onf. 17th, E526-1:536

JOLLIFF B. I. AND HASKIN L. A. (1995) Cogenetic rock fragments from a lunar soil: Evidence of a ferroan noritic-anorthosite pluton on the Moon. Geochim. Cosmochim. Acta 59, 2345-2374.

JOLLIFF B. L., KOROTEV R. L. AND I IASKIN L. A (1991) A ferroan region of the lunar highlands as recorded in meteorites MAC88104 and MAC88105. Geochim. Cosmochim. Acta 55, 3051-3071

KOEBERL C.. WARREN P. H. LINDS'TROM M. M., SPETTEL B. A.ND FUKLLOKA T. (1989) Preliminary examination of the Yamato-860.32 lunar meteorite: II. Major and trace element chemistry. Proc. NIPR Symp. Antarct. Meteorites 2 nd, 15-24.

KofBrRI. C. KuRAT G. AND BRANDSTATTER F. (1990) l unar meteorite Yamato-86032: Mineralogical, petrological, and geochemical studies. Proc. NIPR Symp Antarct. Meteorites 3rd, 3-18.

Korotey R. I.. (1982) Comparative geochemistry of Apollo 16 surface soils and samples from cores 64002 and 60002 through 60007 . Proc. Lumar Planet. $S_{C i}$. Conf. 13th, A269-A278.

KOROTEV R. L. (1983) Geochemical study of individual $1-2 \mathrm{~mm}$ particles from Apollo 16 soil 67712 (abstract). Lunar Planet. Sci. 14, 399-400.

KOROTEV R. L. (1991) Gicochemical stratigraphy of two regolith cores from the Central Ilighlands of the Moon. Proc Lumar Plamet. Sci. Conf. 21st, $229-289$.

KOROTEV R. L. (1994) Compositional variation in Apollo 16 impact-melt breccias and inferences for the geology and hombardment history of the Central Highlands of the Moon. Geochim. Cosmochim. Acta 58, 3931-3969.

KOROTLV R. L. (1996) The composition of the prebasin crust in the Central Highlands of the Moon (abstract). Lumar Planet. Sci. 27, 689-690.

KOROTEY R. L AND HASKIN L. A. (1988) Europium mass balance in polymict samples and implications for plutonic rocks of the lunar crust. Geochim Cosmochim. Acta 52, 1795-1813.

KOROTEV R L.. HASKIN L. A AND LINDSTROM M. M. (1980) A synthesis of lunar highlands compositional data. Proc. Lumar Planet. Sci conf. ilth, 395-429. 
Korotev R. L., HaSkIN L. A. AND JOLliff B. L. (1995) Preliminary compositional and petrographic examination of lunar meteorite QUE93069 (abstract). Lunar Planet. Sci. 26, 791-792.

LAUL J. C. AND PAPIKE J. J. (1980) The lunar regolith: Comparative chemistry of the A pollo sites. Proc. Lunar Planet. Sci. Conf. 11th, 1307-1340.

LAUL J. C. AND SCHMITT R. A. (1973) Chemical composition of Apollo 15 16, and 17 samples. Proc. Lunar Sci. Conf. 4th, 1349-1367.

LINDSTROM M. M. (1984) Alkali gabbronorite, ultra-KREEPy melt rock and the diverse suite of clasts in North Ray crater feldspathic fragmental breccia 67975. Proc. Lunar Planet. Sci. Conf. 15th, C50-C62.

LINDSTROM M. M. AND LINDS'TROM D. J. (1986) Lunar granulites and their precursor anorthositic norites of the early lunar crust. Proc. Lunar Planet. Sci. Conf. 16th, D263-D276.

I.INDSTROM M. M. AND SALPAS P. A. (1981) Geochemical studies of rocks from North Ray Crater, Apollo 16. Proc. Lunar Planet. Sci. Conf. 12th, 305-322.

LindSTROM M. M. AND SALPAS P. A. (1983) Geochemical studies of feldspathic fragmental breccias and the nature of North Ray Crater ejecta. Proc. Lunar Planet. Sci. Conf. 13th, A671-A683.

LSPET (Lunar Sample Preliminary Examination Team) (1973) The Apollo 16 lunar samples: Petrographic and chemical description. Science 182, 23-34.

LUCLY P. G., TAYLOR G. J. AND MALARET E. (1995) Abundance and distribution of iron on the Moon. Science 268, 1150-1153.

MARVIN U. B. AND LINDSTROM M. M. (1983) Rock 67015: A feldspathic fragmental breccia with KREEP-rich melt clasts. Proc. Lunar Planet. Sci. Conf. 13th, A659-A670.

Marvin U. B., LindSTROM M. M., Bernatowicz T. J., PODOSEK F. A. AND SUGlliRA N. (1987) The composition and history of breccia 67015 from North Ray Crater. Proc. Lunar Planet. Sci. Conf. 17th, E471-E490.

MCKAY D. S., BOGARD D. D., MORRIS R. V., KOROTEV R. L., JOINSON P. AND WENTWORTH S. J. (1986) Apollo 16 regolith breccias: Characterization and evidence for early formation in the mega-regolith. Proc. Lunar Planet. Sci. Conf. 16th, D277-D303

MCKINLEY J. P., TAYLoR G. J., KEIL K., Ma M.S. AND SChMitT R. A. (1984) Apollo 16: Impact melt sheets, contrasting nature of the Cayley plains and Descartes mountains, and geologic history. Proc. Lunar Planet. Sci Conf. 14th, B513-B524.

MORRIS R. V., SHE T II. AND HORZ F. (1986) Composition of the Cayley Formation at Apollo 16 as inferred from impact melt splashes. Proc. Lumar Planet. Sci. Conf. 17th, E21-E42.

Mutillberger W. R., HORZ F., SEVIER J. R. AND UlRich G. E. (1980) Mission objectives for geological exploration of the Apollo 16 landing site. In Proc. Conf. Lunar Highlands Crust (eds. J. J. Papike and R. B. Merrill), pp. 1-49. Lunar and Planetary Institute, Houston, and Pergamon Press, New York.

Norman M. D. (1981) Petrology of suevitic lunar breccia 67016. Proc. Lunar Planet. Sci. Conf. 12th, 235-252.

NORMAN M. D., TAYLOR G. J. AND KEIL K. (1991) Additional complexity in the lunar crust: Petrology of sodic anorthosites and sulfur-rich, ferroan anorthosites. Geophys. Res. Lett. 18, 2081-2084

OBERBFCK V. R. (1975) The role of ballistic erosion and sedimentation in lunar stratigraphy. Rev. Geophys. Space Phys. 13, 337-362.

Palme H., SPETTEL B., JOCHUM K. P., DREIBUS G., WeBer H., WECKWERTH G., WANKE H., BISCHOFF A. AND STOFFler D. (1991) Lunar highland metcorites and the composition of the lunar crust. Geochim. Cosmochim. Acta 55, 3105-3122.

Rhodes J. M., Adams J. B., Blanchard D. P., Charette M. P., Rodgers K. V., Jacobs J. W., BRANnON J. C. AND Haskin L. A. (1975) Chemistry of agglutinate fractions in lunar soils. Proc. Lunar Sci. Conf. 6th, 2291-2307.

Rose H. J., JR., BAEDECKER P. A., Berman S., Christian R. P., DWornik E. J., FINKI:LMAN R. B. AND SCHNEPFE M. M. (1975) Chemical composition of rocks and soils returned by the Apollo 15, 16, and 17 missions. Proc. Lunar Sci. Conf. 6th, 1363-1373.

RYDER G. AND NORMAN M. D. (1980) Catalog of Apollo 16 Rocks. NASA Curatorial Branch Publication 52, NASA/JSC, Houston. $1144 \mathrm{pp}$.

RYDER G. AND WOOD J. A. (1977) Serenitatis and Imbrium impact melts: Implications for large-scale layering in the lunar crust. Proc Lunar Sci Conf. 8th, 655-668.

Simkin T., NoONAN A. F., Switzer G. S., Mason B., Nelen J. A. and THOMPSON G. (1973) Composition of Apollo 16 fines 60051, 60052, 64811, 64812, 67711, 67712, 68821, and 68822. Proc. Lunar Sci. Conf Ath, 279-289.
Simon S. B., Papike J. J., laul J. C., Hughes S. S. And SCHMITt R. A (1988) Apollo 16 regolith breccias and soils: Recorders of exotic component addition to the Descartes region of the moon. Earth Planer Sci. Lett. 89, 147-162

SPUDIS P. D. (1984) Apollo I6 site geology and impact melts: Implications for the geologic history of the lunar highlands. Proc. Lumar Planet Sci. Conf. 15th, C95-C107.

STOFFLER D., KNÓLl H.-D. AND MAERZ U. (1979) Terrestrial and lunar impact breccias and the classification of lunar highland rocks. Proc. Lunar Sci Conf. 10th, 639-675.

StÖFfler D., KNÖI. I. H.-D., MARvin U. B., SimondS C. II. AND WARREN P. H. (1980) Recommended classification and nomenclature of lunar highlands rocks-a committee report. In Proc. Conf. Lumar Highlands Crust (eds. J. J. Papike and R. B. Merrill), pp. 51-70. L.unar and Planetary Institute, Houston, and Pergamon Press, New York.

StöfFler D., BISCHOFF A., BORCHARDT R., Burghele A., DEUTSCI A., Jessberger E. K., Ostertag R., Palme H., Spettel B., Reimol.d W. U. AND WANKE H. (1985) Composition and evolution of the lunar crust in the Descartes highlands, Apollo 16. Proc. Lunar Planet. Sci. Conf. 15th, C449-C506.

TAKeda H., MiYamoto M., MORI II., Wentworth S. J. AND MCKay D. S (1990) Mineralogical comparison of the Y86032-type lunar meteorites to feldspathic fragmental breccia 67016. Proc. Lunar Planet. Sci. Conf. 20th, $91-100$

TAylor G. J., Warren P., Ryder G., Delano J., Pietirs C. and LOFGREN G. (1991) Lunar Rocks. In Lunar Sourcebook (cds. G Heiken, D. Vaniman, and B. M. French), pp. 183-284. Cambridgc Univ. Press, Cambridge.

TAYloR S. R., GORTON M. P., MUIR P., NANCE W. B., RLidOWSN R. AND WARE N. (1973) Composition of the Descartes region, lunar highlands. Geochim. Cosmochim. Acta 37, 2665-2683.

ULRICH G. E. (1981) D2. Geology of North Ray Crater. In Geology of the Apollo 16 Area, Central Lunar Highlands (eds. G. E. Ulich et al.), pp. 45-81. U. S. Geol. Surv. Prof. Paper 1048.

Wanke H., Baddenhausen H., Dreibus G., Jagoutz I., Kruse H., PAlME H., SPETTEL B. AND Tesclike F. (1973) Multielement analyses of Apollo 15, 16, and 17 samples and the bulk composition of the Moon. Proc. Lunar Sci. Conf. 4th, 1461-1481.

Wanke H., Palme It., Baddenhausen H., Dreibus g. Jagoutz E., KRUSE II., SPLTtEl B., TESChKE F. AND THACKER R. (1974) Chemistry of Apollo 16 and 17 samples: Bulk composition, late stage accumulation and early differentiation of the moon. Proc. Lumar Sci. Conf. 5th, 1307-1355.

Wánke H., Palme H., Baddeniausen H., Drlibus (j., Jagoutz E. Kruse H., Palme C., Spettel B., Teschíe F. and ThaCker R. (1975) New data on the chemistry of lunar samples: Primary matter in the lunar highlands and the bulk composition of the moon. Proc. Lunar Sci. Conf. 6th, 1313-1340

Wänke H., Palme H., K'ruse H., Baddenhausen H., Cendales M. Dreibus G., Hofmeister H., Jagoutz E., Palme C., SPEtTle B. and THACKER R. (1976) Chemistry of lunar highlands rocks: A refined evaluation of the composition of the primary matter. Proc. Lunar Sci. Conf. 7th, 3479-3499.

Warner R. D., Planner H. N., Keil K., Murali A. V. Ma M-S. SChmitt R. A., EhmanN W. D., James W. D., JR., Clayton R. N. AND MAYEDA T. K. (1976) Consortium investigation of breccia 67435. Proc. Lunar Sci. Conf. 7th, 2379-2402.

WARREN P. H. (1990) Lunar anorthosites and the magma-ocean plagioclase-flotation hypothesis: Importance of $\mathrm{FeO}$ enrichment in the parent magma. Am. Mineral. 75, 46-58.

WARREN P. H. AND KALLEMEYN G. W. (1991) Geochemical investigations of five lunar meteorites: Implications for the composition, origin and cvolution of the lunar crust. Proc. NIPR Symp. Antarct. Meteorites 4th, $91-117$

WARREN P. H. AND WASSON J. T. (1978) Compositional-petrographic investigation of pristine nonmare rocks. Proc. Lumar Sci. Conf 9th, 185-217.

Wasson J. T., WARREN P. H., KallemeYN G. W., MCEWING C. E., MITTLEFEHLDT D. W. AND BOYNTON W. V. (1977) SCCRV, a major component of highlands rocks. Proc. Lunar Sci. Conf. 8th, 2237-2252.

WENTWORTH S. J. AND MCKAY D. S. (1988a) The significance of glass fragments in feldspathic fragmental breccia 67016 (abstract). Lunar Planet Sci 19, 1263-1264.

WENTWORTH S. J. AND MCKAY D. S. (1988b) Glasses in ancient and young Apollo 16 regolith breccias: Populations and ultra $\mathrm{Mg}^{\prime}$ glass. Proc. Lunar Planet Sci. Conf. 18th, 67-77. 